\title{
Genre and Attitude to Support Character Development in Children Stories
}

\author{
Riyadi Santosa, ${ }^{*}{ }^{*}$ Djatmika Djatmika, ${ }^{2}$ Dyah Ayu Nila Khrisna ${ }^{3}$
}

${ }^{1}$ Program Studi Sastra Inggris, Universitas Sebelas Maret, Jebres, Surakarta 57126, Indonesia

*) Corresponding Author

Email: riyadisantosa@staff.uns.ac.id

DOI: $10.18326 /$ rgt.v14i1.83-98

Submission Track:

Received: 16-01-2021

Final Revision: 28-03-2021

Available Online: 01-05-2021

Copyright (C) 2021 Authors

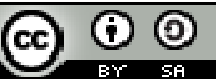

This work is licensed under a Creative Commons Attribution-ShareAlike 4.0 International License.

\begin{abstract}
This paper examines how character development is analyzed through attitude, genre's stages and phases in children stories. Relying on ten children's stories purposively selected from two children's story books, the results show that all of ten stories are written as narrative with a number of absences of attitude, stages and phases of narrative genre. most stories succeed to fulfill the obligatory stages of narrative: orientation, complication, evaluation, and resolution, even others add the optional stage, coda. However, a number of stories fail to satisfy the presence of evaluation. in addition, all stories do not exploit attitude in every phase of every stage of narrative. Even, a number of stories miss to exploit Attitude in a number of prominent phases such as introducing character in orientation, development and peak of conflict in complication, and plan and act in resolution. Besides, all ten stories do not explore all types of attitude and their sub-classifications, in which each type will contribute to holistic description of character. Thus, although all stories can be considered to develop character along the obligatory stages of the narrative genre, but they still fail to build a more complexed character development through positive-negative-positive evaluation through stages and phases of the stories.
\end{abstract}

Keywords: character development; genre; stages; phases; attitude 


\section{INTRODUCTION}

Stories, including children's stories, depict characters and their sociopsychological values through the genres of the stories. The characters are pictured as human beings so that they are carved or marked in a number of human habits that cause the character to do something according to the carvings (O'Sullivan, 2004). The characters' deeds are derived from the moral and intellectual power they have. In this sense, the characters will always be judged to have good or bad moral and intellectual quality or what is called human traits or character values. The traits or values include key principles and values such as honesty, tolerance, trust, equility, kindness, generosity and respect for differences or others and the opposites (Almerico, 2014).

Characters in children's stories are often represented as human beings or animals. The quality of the characters can be accommodated by various sources of storytelling, either through direct description by the authors, interaction between one character with another, or through the assessment of other characters in the story, both the direct character's appraisal or the appraisal of goods or bad institutions related to the characters (Martin \& Rose, 2007; Martin \& White, 2005). In addition, character development will also be built up through the socio-psychological development of characters in dealing with problems and solving problems. The development of characters like this can be assessed through the stages and phases of the narrative genre of the story (Martin, 1992; Martin and Rose, 2007; Rose, 2010).

Many studies on children's stories used to develop character in schools have been conducted. Children's stories are often effective tools for introducing characters (Cartledge \& Kiarie, 2001; Santosa et al, 2007; Leming, 2010; Almerico, 2014). However, the research of Djatmika, Primasita, and Priyanto (2011) shows that children still have difficulties in developing stories according to their genre. This is due to the fact that their stories fall into recount or exemplum rather than narratives. Meanwhile, another Djatmika's (2012) research also shows that children still have weaknesses in exploiting grammar in developing characters. They still lack of knowledge of use of conjunction, attitudinal lexis, and metaphor. Besides, research on appraisal analysis of children stories still fail to comply a holistic view since the stories are only viewed from the appraisal or evaluative language only excluding involving 
staging and phases (Fitriati et al, 2018; Shiro, 2003). Based on the phenomenon above, this article is written to see how characters are developed in children stories based on genre and appraisal analysis, particularly through ATTITUDE system.

Children's stories are often defined as a form of literary work written for the target audience of children. In addition, the children's stories can also categorized as stories written by children (Djatmika et al, 2011; Djatmika, 2012).

Generally, these children's stories are in narrative genre, but often the writer also presents the stories in recount, or even in anecdote and exemplum genres (Djamika et al, 2011). As a narrative, then, the story is developed through obligatory stages, such as orientation, complications, evaluation, and resolution; and may be added by an optional stage called coda (Martin, 1992; Martin \& Rose, 2007; Rose 2010) . The stages are often constructed through phases which break the stages into more detailed rhetorical functions (Martin \& Rose, 2007, Rose, 2007). Breaking stories into stages and phases can often make writes too focused on the four stages but fail to produce smooth stories. The narrative must be dynamic and the story line must have a smooth interwoven story so that the reader does not feel the existence of the division during the reading (Tan, 2011).

The power of narratives lies in how complication and resolution are strongly built. The conflict is developed through logical and complexed events encountered between and among characters that rise to the peak. Meanwhile, the solution for such a conflict is planned logically and deliberately to resolve the conflict (Erdmann, 2009; Segal, 2010). In these stages, the writers are challenged to exploit the appropriate use of lexicogrammar and discourse semantics, including appraisal system to instantiate the development of characters.

As can be seen in the previous part, character values are carved in the characters along the story lines. This means that characters in narrative should not only be introduced but also be developed through stages are developed. What and how the characters are built must also be learnt to develop characters in narratives (Widyahening \& Wardhani, 2016; Inderawati, 2012; Tyra, 2011; Leming, 2010; Feldman, 2014). The character development will 
also exploit the use language as a medium of expression (Tan, 2011). The linguistic aspects that can be deployed to see such a character development process are appraisal system and narrative genres (Martin \& Rose, 2007, Rose 2007).

Genre is defined as the smallest cultural unit having that occurs repeatedly in a society (Martin, 2014). It represents a social process which produces a social goal and governs how the social goal is achieved. The goal is realized through stages and phases. In reality, genre is realized in the context of a particular situation into a register, configurations of meaning of Field, Tenor, and Mode. This configuration of meaning is instantiated in the use of languages, which consist of discourse semantic, lexicogrammar, and phonology/ graphology (Hasan, 2014, Martin, 2014; Matthiessen, 2015a \& b; Matthiessen \& Khasyaf, 2014). In this context, often, genre may be similar to text type as each shows different linguistic features (Tan, 2011) although they are in different semiotic layers.

There are two types of written genres, namely the story genre and the factual genre (Martin, 1992; Santosa, 2003; Rose, 2007). The former consists of four types namely, recount, anecdote, exemplum, and narrative. These texts are different to each other in accordance to the way the events are responded by the participant in the plot of the story. A recount presents events which are arranged in a chronological order. Meanwhile, in anecdotes, events that occur are unusual that often make the culprit embarrassed or sad, so that s/he react affectively in an expression of negative feelings and results in humor or symphaty. On the other hand, an exemplum of the event is an incident, which is an extraordinary event that is usually undesirable. The character tends to make interpretation following the event, so that s/he can get morals behind the event. Finally, a narrative begins with the introduction of characters, settings, and events, then followed by the emergence of problems. This problem is developed in an increasing manner so that at a certain point it results in an evaluation of the problem's resolution. it closes with an attempt to resolve the problem, resolution. Sometimes a narrative has another optional unit named as Coda in which moral of the story is presented (Martin, 1992; Rose, 2007). Meanwhile, the factual genre consists of eight types, namely description, report, recount, procedure, explanation, exposition, discussion, and exploration. Factual genre is not elaborated here because this research is only limited to the story genre. 
In a genre, stages will also be furthered structured into phases. The phases will resemble a series of events that functionally construct the stages (Martin \& Rose, 2007; Rose, 2010). However, Martin \& Rose's (2007) concept of phases is less detailed that the result is operational to be used for character development in children's stories. Meanwhile, Rose's (2010) classification of phases in stories moves continuously across stages. Thus, they cannot be identified to what stages they belong to. I would rather break stages more functionally according to what have been done more rigorously by literary analysts (Erdmann, 2009; Segal, 2010). In addition, the phases are connected with the use of ATTITUDE so that the result is more functional to analyze character development in stories. In brief, orientation introduces characters, setting, and activity. complication introduces problems, develops problems to the peak of the conflict. Meanwhile, evaluation tells the main character's contemplation of the problems they face, and resolution is a series of phases of planning to solve problem, acting the plan, and resolve the problem. Within the stages and phases, the register will exploit the use of language, including ATTITUDE in appraisal system (Rose, 2007).

ATTITUDE is a part of appraisal system which, together with GRADUATION and ENGAGEMENT, realize interpersonal meaning at the discourse level. It is a part register choice realizing the configuration of meaning in field, tenor and mode. The choice involves the discourse semantic and lexicogramatical systems. In a spoken discourse the choice will also include phonological system and in a written discourse the choice may also involve graphological system (Martin \& White, 2005; Martin \& Rose, 2007). ATTITUDE includes expressions of feeling (affect), evaluation towards character or behaviour (judgement), and valuation of things/social institutions (appreciation). Expressions of feelings consist of expressions of inclination/disinclination, happiness/unhappiness, security/insecurity, and satisfaction/dissatisfaction. Each of these expressions has more detailed sub-categories (Martin, 2017; Martin \& Rose, 2007; Martin \& White, 2005). Judgement or character evaluation consists of two broad categories, namely self esteem and social sanctions. The former is divided into normality (fate), capability, and tenacity; whereas the later consists of two parts, namely honesty (veracity) and ethics (propriety). Finally, appreciation representes three main parts: reaction, composition and valuation. Reaction consists of two sub-categories: impact and quality; composition consists of a 
balanced and complex composition; and valuation is a matter of the usefulness of the goods (Martin \& Rose, 2007; Martin \& White, 2005).

The three systems of ATTITUDE-affect, judgement, and appreciation can be used to identify the character and its development in a narrative. Affect can be used to identify the development of characters' positive or negative feeling towards each other. Judgement can be explored to see good or bad evaluation towards the characters, whereas appreciation can be used to explore the evaluation of characters' things and their social institutions (Rose, 2007; Fitriati et al, 2018).

\section{RESEARCH METHOD}

This research is a discourse analysis inspired by Systemic Functional Linguistic (SFL), especially deploying genre and appraisal analyses. This research is qualitative in nature which aims to see the development of characters in a story. The study looks closely at how the evaluative choices instantiated contribute to the establishment of stages and phases in narratives. In addition, a look into the character development is taken into account through attitude resources and their distribution in the stages and phases of the stories (Tupala, 2019).

Two books-the special edition of Kecil-Kecil Punya Karya, published by Dar Mizan Bandung (2011) and Tangan-Tangan Mungil Melukis Langit (Collection of Short Stories), published by Mizan Media Utama Bandung (2006) were analysed in this study. The two books were chosen due to the fact that they are written by children between year four and year six of elementary schools. Of the two books ten stories were chosen purposively by looking at the completeness of the stages and phases of the genre and the completeness of the attitude system exploited in the stories (Spradely, 2006). The data are in the form of attitude system, which were analysed through the stages of analyses: domain, taxonomic, componential, and cultural theme analyses. Domain analysis found the context of use, particularly types of genres, stages, and phases in the stories. Taxonomic analysis identified the types of attitude used in the stories, componential analysis combined the results of domain and taxonomic analyses to find the patterns of use of attitude in the stories. Finally, 
cultural theme analysis interpreted and discussed the patterns in a larger context of use (Santosa, 2017).

\section{RESULTS AND DISCUSSION}

\section{Genre, Stages, and Attitude of Children Stories}

It can be seen from Table 1 that domain analysis shows all ten stories have completed three obligatory stages of narrative - orientation, complication, and resolution. Seven of them add one more obligatory stage - evaluation and four stories have an additional stage coda. This means that almost all stories have satisfied Martin and Rose's (2007) and Rose's (2007) obligatory stages of narrative. The phases vary across the stages in the stories. But, for the purpose of analysis all possible phases in stages are introduced in domain analysis. Orientation introduces character, setting, and activity. Complication introduces, develops and raises the conflict or problems into peak. Evaluation provides chances for the characters to think of the conflict. Resolution starts with planning, acting, and resolving the conflict (Erdmann, 2009; Segal, 2010).

Meanwhile, taxonomic analysis in Table 1 indicates that the 10 stories deploy all types of attitude that involve affect, judgement, and appreciation, including the more detailed sub-classification of each category (see Martin \& Rose 2007). Componential analysis combines domain and taxonomic analyses into a complexed matrix. The matrix of Table 1 compresses the use of attitude into positive and negative categories to find out how the patterns of character development are constructed through attitude in stages and phases (Tupala, 2019). Finally, cultural theme analysis interprets and discusses the patterns in a wider context to find out the cultural values of the genre and attitude in children's stories (Santosa, 2017).

As mentioned in literature review, characters will not only be described but also be developed through the whole stories (Widyahening \& Wardhani, 2016; Inderawati, 2012; Tyra, 2011; Leming, 2010; Feldman, 2014). However, Table 1 also shows that not all stories exploit attitude in all stages and phases. Although every phase may not constitute obligatory elements of the stages, the use of attitude at all phases will contribute to the development of characters in the stories (Martin \& Rose, 2007). Stories 1, 4, 7, 8, and 9 just develop attitude in 
the introducing characters' activities, while stories 2, 3 and 10 miss the setting. Only story 5 builds their characters through the attitude almost in all phases of orientation: introducing characters, and activities. In complication, stories 3 and 4 do not apply attitude in developing conflict into peak, whereas stories 5 and 7 do not explore attitude in conflict development and peak. In addition, stories 6 , 8,1 nd 9 do not exploit attitude in plan whereas story 10 do not construct both plan and act. Finally, only stories 5, 6, 7, and 9 have coda with attitude.

Table 1

Distribution of Attitude in Stages and Phases in 10 Stories

\begin{tabular}{|c|c|c|c|c|c|c|c|c|c|c|c|c|}
\hline \multirow{3}{*}{ Staging } & \multirow{3}{*}{ Phases } & \multicolumn{10}{|c|}{ Attitude } & \multirow{3}{*}{$\Sigma$} \\
\hline & & 1 & 2 & 3 & 4 & 5 & 6 & 7 & 8 & 9 & 10 & \\
\hline & & $\begin{array}{c}+ \\
(-)\end{array}$ & $\begin{array}{c}+ \\
(-)\end{array}$ & $\begin{array}{c}+ \\
(-)\end{array}$ & $\begin{array}{c}+ \\
(-)\end{array}$ & $\begin{array}{c}+ \\
(-)\end{array}$ & $\begin{array}{c}+ \\
(-)\end{array}$ & $\begin{array}{c}+ \\
+(-)\end{array}$ & $\begin{array}{l}+ \\
(-)\end{array}$ & $\begin{array}{l}+ \\
(-)\end{array}$ & $\begin{array}{c}+ \\
(-)\end{array}$ & \\
\hline \multirow[t]{6}{*}{ Orientation } & Character & - & 7 & 6 & - & 1 & - & - & - & - & 2 & 16 \\
\hline & & - & - & - & - & -3 & -2 & - & - & - & -1 & -6 \\
\hline & Setting & - & - & - & - & - & 1 & - & - & - & - & 1 \\
\hline & & - & - & - & - & - & - & - & - & - & - & - \\
\hline & Activity & 13 & 3 & 6 & 18 & 3 & 7 & 2 & 1 & 3 & 6 & 62 \\
\hline & & -3 & -6 & -1 & -16 & - & -9 & -1 & -9 & -2 & - & -50 \\
\hline \multirow[t]{6}{*}{ Complication } & Introduction & 1 & 4 & 5 & 8 & 4 & 2 & 1 & 18 & 5 & 15 & 63 \\
\hline & & -9 & -7 & -4 & -12 & -1 & -4 & -2 & -12 & -2 & -1 & -54 \\
\hline & Development & 33 & 17 & 1 & 1 & - & 13 & - & 3 & 6 & 4 & 78 \\
\hline & & -3 & -20 & -4 & -3 & - & -19 & - & -9 & -14 & -1 & -73 \\
\hline & Peak & 9 & 5 & - & - & - & 3 & - & 1 & - & 9 & 27 \\
\hline & & -1 & -18 & - & - & - & -8 & - & -3 & -9 & -3 & -42 \\
\hline \multirow[t]{2}{*}{ Evaluation } & & 2 & 2 & 3 & 4 & 2 & - & 1 & - & 1 & - & 15 \\
\hline & & -3 & -3 & - & -8 & -1 & - & -2 & - & -7 & - & -22 \\
\hline \multirow[t]{6}{*}{ Resolution } & Plan & 1 & 1 & 1 & 1 & 1 & - & 4 & - & - & - & 9 \\
\hline & & - & - & - & -2 & - & - & - & - & - & - & -2 \\
\hline & Act & 4 & 13 & 56 & 8 & 15 & 12 & 9 & 2 & 5 & - & 124 \\
\hline & ACt & -2 & -26 & -16 & -3 & -7 & -9 & - & -3 & -1 & - & -67 \\
\hline & Resolved & 11 & 8 & 3 & 3 & 5 & - & 3 & 2 & 6 & 1 & 42 \\
\hline & & - & -7 & - & -3 & -6 & -5 & - & -3 & -1 & - & -25 \\
\hline \multirow[t]{2}{*}{ Coda } & & - & - & - & - & 2 & 1 & 1 & - & 1 & - & 5 \\
\hline & & - & - & - & - & - & - & - & - & - & - & - \\
\hline
\end{tabular}

Note:

1, 2, 3...: Story1, Story 2, Story $3 \ldots$

It can also be seen in Table 1 that all ten stories are started with positive or negative orientation, developed in positive and negative complication, and ended with more positive resolution. this means that in orientation, characters are portrayed in more positive attitude introducing character and activities. Then, the characters are depicted in more negative rather positive attitude through introduction of conflict, development and more emphasis in peak of complication and evaluation. Then, the characters make positive plans to 
resolve the conflict. The plan is realized in more positive acts and the conflicts are resolved in positive ways before the whole stories are commented positive in coda. Thus, the characters in the stories have passed through their lives, beginning from positive, negative, and resulting in positive experience in the stories. This positive-negative-positive experience has already satisfied the development of attitude in narrative genres (Martin, 1992; Rose, 2007; Widyahening \& Wardhani, 2016; Inderawati, 2012; Tyra, 2011; Leming, 2010; Feldman, 2014).

\section{Distribution of Attitude in Stages and Phases}

Due to the lack of space, this article will not be able to display all of the stories into one matrix of componential, containing genre stages, phases, and all types of attitude. For this reason, only story 5 and 10 are selected according to the less to most complete stages and phases to be displayed in this article.

As mentioned earlier in the discussion of genre, stages and attitude, although the ten stories have completed the obligatory elements of narrative, they fail to satisfy the phases of the stories. Besides, they also fail to explore all types of attitude in their stories. For example, story 5 do not explore the use of affect: unhappiness; satisfaction and dissatisfaction; judgement: moral sanction: veracity, and propriety; and appreciation: composition: balance and complexity; valuation. The absence of these attitude aspects varies in the 10 stories. This may be due to the writer's maturity and experience. However, fulfilling the obligatory stages of narrative and the major phases of the stages are somethings that we should appreciate, since they still make mistakes in lexicogrammatical structures and systems in writing stories (Djatmika et al, 2011; Djatmika 2012; Fitriati 2018; and Shiro 2003).

As can be seen in Table 2, story 5 is constructed without ATTITUDE in introducing setting in orientation and without development of conflict and peak in complication. The absence of evaluation in Setting will lessen to support the holistic picture of the character (Martin, 1992; Widyahening \& Wardhani, 2016; Inderawati, 2012; Tyra, 2011; Leming, 2010; Feldman, 2014). But it seems that the writer has the ability to evaluate characters through ATTITUDE. For example,

(1) Titok Hestitok namanya. Bocah laki- laki yang senang makan permen di luar sekolah itu, sering berhalusinasi kadang- kadang. 
(Tiktok Hestitok is his name. The boy who likes to eat sweets outside school sometimes hallucinates)

(2) Melihat suatu bayang- bayang. Ihhhh... mengerikan. Bahkan, Gareng takut kepadanya.

(He sees figures. Hmmm... fearing. Even, Gareng fears of him).

Table 2

Distribution of ATTITUDE in Story 5

\begin{tabular}{|c|c|c|c|c|c|c|c|c|c|c|c|c|}
\hline \multirow{3}{*}{ Stages } & \multirow{3}{*}{ Phases } & \multicolumn{5}{|c|}{ Affect } & \multirow{2}{*}{\multicolumn{3}{|c|}{$\begin{array}{l}\text { Judgement } \\
\text { Social Esteem } \\
\end{array}$}} & \multirow{2}{*}{\multicolumn{2}{|c|}{$\begin{array}{l}\text { Appreci. } \\
\text { Reaction }\end{array}$}} & \multirow{3}{*}{$\sum$} \\
\hline & & \multicolumn{2}{|c|}{ Inc/Disi } & \multirow{2}{*}{$\begin{array}{l}\mathrm{Ha} \\
+ \\
\end{array}$} & \multicolumn{2}{|c|}{$\mathrm{Sec} / \mathrm{In}$} & & & & & & \\
\hline & & + & - & & + & - & Nor & $\mathrm{Ca}$ & Ten & $\operatorname{Im}$ & Qua & \\
\hline Orientation & $\begin{array}{l}\text { Char } \\
\text { Setting }\end{array}$ & & 1 & 1 & & & & & -1 & -1 & & 4 \\
\hline & Activity & 1 & 1 & 1 & & 1 & & & 1 & & & 5 \\
\hline Complication & $\begin{array}{l}\text { Intro } \\
\text { Dev } \\
\text { Peak }\end{array}$ & 1 & & 1 & 1 & 1 & & & & & 1 & 5 \\
\hline Evaluation & & & & & & 1 & & & & & 2 & 3 \\
\hline Resolution & Plan & 1 & & & & & & & & & & 1 \\
\hline & Act & 7 & & 2 & 2 & 1 & 1 & -1 & -1 & -4 & 3 & 22 \\
\hline & Resolve & -1 & & 1 & 1 & & & & $3,-5$ & & & 11 \\
\hline Coda & & 2 & & & & & & & & & & 2 \\
\hline$\sum$ & & 12 & & 6 & 4 & 4 & 4 & 1 & 10 & 7 & 6 & 54 \\
\hline
\end{tabular}

Notes:

Stages and Phases: Char: Character; Introduction of conflict; Dev: Development of conflict; ATTITUDE: Inc: Inclination; Disi: Disinclination; Ha: Happiness; Sec: Security; In: Insecurity; Nor: Normality; Ca: Capacity; Ten: Tenacity; Appreci: Appreciation; Im: Impact; Qua: Quality

The introduction of Tiktok is started with positive but rather negative affect: happiness: cheer "... senang makan permen ..." (“... likes to eat sweets...) and negative social esteem: tenacity "... kadang-kadang berhalusinasi..." (... sometimes hallucinates) in clause 1 . Then, it continues with Titok's friend, Gareng's, comments on his physical appearance in negative appreciation: impact “... bayang-bayang... mengerikan... (... figures ... frightening) and negative affect: disinclination: fear "Gareng takut takut kepadanya." (Gareng fears of him) in clause 2.

After leaving setting without evaluation, the orientation continues with introducing activity. The following clauses depict the activities.

(1) "Enak lho, uang jajan ku habis karena untuk aku jajan permen itu!" pamer Titok.

(It is fun to spent my money to buy sweets," boasted Titok) 
(2) Temannya, Titok terus mengajaknya membeli permen di luar sekolah sehingga ia menjadi anak yang boros sekarang.

(His friend, Titok, continued asking him to buy sweets outside school so he became a wasteful boy.)

(3) Gareng tentu tidak mau, karena ia membawa bekal. (Gareng, of course, did not want it, because he brought his meal)

(4) Selain itu, ia menghemat uang jajan untuk membeli sepeda. (Besides, he spent his money wisely to buy a bicycle.)

The writer begins introducing Activity with evaluating Titok' activities in positive affect: happiness: cheer "Enak lo," (It's fun...) in clause 1. The he continues with negative affect: security: confidence: “... terus mengajak membeli permen..." (... Continued asking him to buy sweets...) and negative judgement: social esteem: tenacity: “... Dia menjadi anak yang boros..." (... he became a wasteful boy...) in clause 2. But the writer reevaluates it with Gareng's response in negative affect: inclination: desire "Gareng tidak mau..." (Gareng didn't wanted ....) in clause 3 and positive affect: inclination: desire "ia menghemat uang jajan ..." (... he spent the money wisely to ...) in clause 4 .

Thus, the absence of evaluation on introducing Setting a little bit corrupt the picture of 'outside school'. The reader will miss 'what is it like' or 'what kind of place is it'. In that case, it will not support the place where the character like to be around.

Meanwhile, the absence of development of conflict and peak in complication will, of course, reduce the complicatedness of the developed conflicts. The conflicts or problems seem to like 'not finished' Erdmann, 2009; Segal 2010). In story 5 the complication is constructed through introduction of conflict, where Tiktok's, the antagonist, feeling and evaluation on his activity are challenged by Gareng, the protagonist. For example,

(1) "Wah! Wah! Wah! Pasti enak kalau ngemut permen sambil main games di komputer...

("Wow! Wow! Wow! It must be nice to have sweets while gaming in computer...)

(2) Titok pun datang membawa sekantung plastik besar bewarna hitam. (Tiktok came carrying a big black plastic bag) 
(3) "Ya, ampun Tiitok! Kamu itu apa- apaan sih? Ngabis- ngabisin duit aja deh. Itu namanya pemborosan lho, tok!" nasihat Gareng.

("My dear, Tiktok! What are you doing? You're just wasting your money. That's wasting money, Tok!" advised Gareng)

(4) "Nggak apa- apa biarin! Titok bisa minta uang sama Mami! Mami kan baik!" balas Titok sambil berlalu pergi.

("I don't care! Tiktok can ask Mummy for money! My mummy is kind-hearted, isn't she?" replied Tiktok while leaving).

Tiktok's positive affect: happiness: cheer: disposition, “Wah! Wah! Wah!” ("Wow..."), positive security: confidence: disposition "Pasti enak... (It must be nice") in clause 1 , and positive appreciation: reaction: quality “... sekantung plasktik besar berwarna hitam" ("... a big black plastic bag.") in clause 2 are reevaluated by Gareng's positive inclination: desire "...! nasehat Gareng." (“... advised Gareng) in clause 3. Then, Tiktok leaves Gareng with negative affect: insecurity: disquiet: urge of behavior "... balas Tiktok sambal berlalu pergi." (... replied Tiktok while leaving) in clause 4. Leaving friend after being challenged is, of course, not enough for developing conflict in complication. This introduction of conflict needs to be advanced by the development of conflict into peak.

Finally, story 5 has not exploited the possibility of the presence all types of sub-ATTITUDES. For example, story 5 just explores a number of sub types of ATTITUDE such affect: unhappiness, judgement: social sanction of veracity and propriety, and appreciation: composition and valuation. The judgement: social sanction of veracity and propriety is potential to evaluate the presence or the absence of truth and ethics in society whereas appreciation of composition and valuation can also be used to evaluate the complexity of things and institution that can also generate and raise the conflict (Martin \& Rose, 2007; Martin \& White, 2005).

The absence of phases and a number of ATTITUDES can also be seen in story 10, depicted in Table 3. Story 10 has just missed a lot of phases in character development. For example, it does not only fail to develop the introduction of setting in orientation but it also fails to explore evaluation and plan and act in 
resolution. Even, the writer has just resolved the conflict with the only one ATTITUDE: negative affect: insecurity. Besides, it has no coda introduced in the story. Theoretically, although the writer has succeeded to produce the complexed complication, the writer fails to respond it with a complexed Resolution. Even, the writer has finished the story with one negative Affect: Insecurity. It can be said that the characters have not been developed through positive-negative- positive phases of character development in narratives (Martin, 1992; Rose, 2007).

Table 3

Distribution of ATTITUDE in Story 10

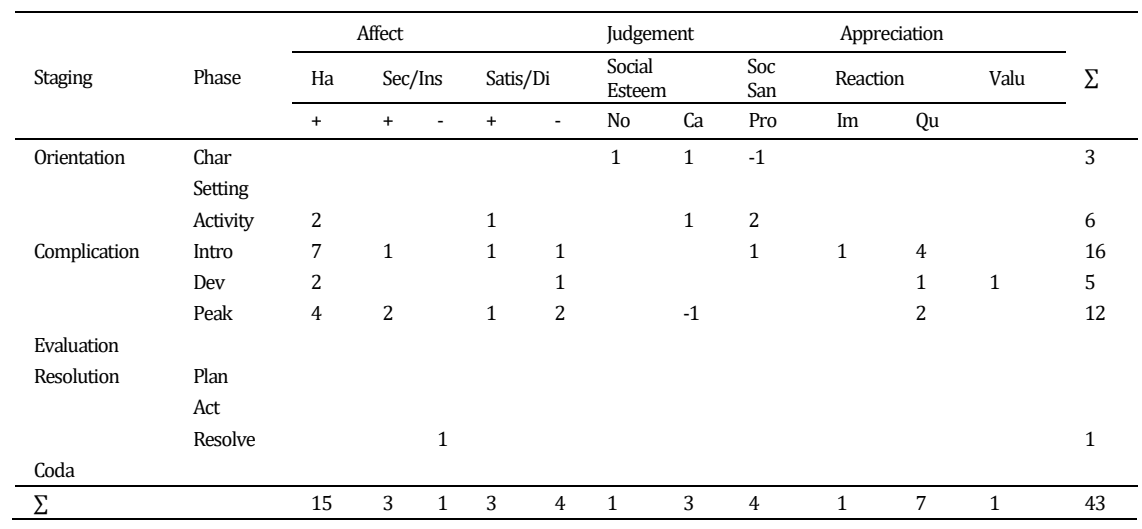

\section{Notes:}

Stages and Phases: Char: Character; Intro: Introduction of conflict; Dev: Development of conflict; ATTITUDE: Ha: Happiness; Sec: Security; Ins: Insecurity; Satis: Satisfaction; Di: Dissatisfaction; Soc San: Social Sanction; Pro: Propriety; No: Normality; Ca: Capacity; Pro: Propriety; Im: Impact; Qu: Quality; Valu: Valuation

In addition, story 10 also fail to exploit other types of ATTITUDES such as affect: inclination and disinclination that usually are used to generate desire and fear. The affect: inclination: desire is, particularly, very important to develop the willingness to resolve the conflict, which is usually realized in evaluation or in resolution: plan (Martin \& Rose 2007; Martin \& White, 2005). I can be said that Story 10 also fail to exploit ATTITUDE holistically, thus, Story 10 also fail to develop character through the whole story (Widyahening \& Wardhani, 2016; Inderawati, 2012; Tyra, 2011; Leming, 2010; Feldman, 2014). 


\section{CONCLUSION}

Based on the findings and discussion above, it can be summarized that seven children stories have fulfilled the obligatory stages of the narrative genre, involving orientation, complication, evaluation and complication. Even, four of the stories have added with the optional stage, coda. Meanwhile, it can also be found that three of them fail to satisfy the presence of Evaluation in the stories. Secondly, it can also be said that all stories fail to fulfill the whole phases of every stage in the narrative. Just to mention, five stories do not fulfill Introduction of character and setting; and only five stories develop Introduction of character without setting in complication. Thirdly, although most stories have completed phases in complication, two stories have no development and peak of conflict and two others cannot finish the peak in complication. Finally, three stories fail to satisfy the plan in resolution and another story misses the plan and act and just leave one negative affect: insecurity to resolve conflict.

Based on the distribution of ATTITUDE in stages and phases of narrative, it can be said that all stories have not experienced through positive-negative-and positive stages of character development. It can also be said that not all types of and sub-types of ATTITUDES are exploited to develop characters in the stories.[rgt]

\section{REFERENCES}

Almerico, G.M. (2014). Building character through literacy with children's literature. Research in Higher Education Journal, 24, 1-13.

Cartledge, G. \& Kiarie, M.W. (2001). Learning social skills through literature for children and adolescents. Teaching Exceptional Children. 34 (2) 40-47.

Djatmika, D. (2012). Kualitas olah bahasa anak usia sekolah dasar dalam kegiatan bercerita: Sebuah proses pemerolehan bahasa anak. Metalingua Jurnal Penelitian Bahasa.10 (2).

Djatmika, D., Primasita, F. A. \& Priyanto, A. D. (2011). Strategi meningkatkan kualitas olah bahasa untuk cerita pendek tulisan siswa sekolah dasar dengan pendekatan genre-based. Jurnal Ilmu Bahasa dan Sastra Lingua. 6 (2). 
Erdmann, E. (2009). Nationality international: Detective fiction in the late twentieth century. Translated by Fiona Fincannon. First published in: Murti, et. al., Investigating identities: Questions of identity in contemporary international crime fiction. Edited by Marieke Krajenbrink. Rodopi.11-26. http://uni-kontanz.de/bitstream/ handle/123456789/3567.

Feldman, M.P. (2014). The character of innovative places: entrepreneurial strategy, economic development, and prosperity. Small Business Economics, $43,9-20$.

Fitriati, S. W., Solihah, Y. A., \& Tusino. (2018). Expressions of attitudes in students' narrative writing: An appraisal analysis. Lingua Cultura, 12(4), 333-338. https://doi.org/10.21512/lc.v12i4.4789.

Hasan, R. (2014). Towards a paradigmatic description of context: systems, metafunctions, and semantics. Functional Linguist, 1 (9). https://doi.org/ 10.1186/s40554-014-0009-y

Inderawati, R. (2012). The development of literary appreciation instrument in building students' character. Sino-US English Teaching, 9 (2), 937-945.

Leming, J. S. (2010). Tell me a story: An evaluation pf a literature-based character education programme. Journal of Moral Education, 29, 413-427. https://doi.org/10.1080/713679388

Martin, J. R. (1992) English text: System and structure. John Benjamin.

Martin, J. R. \& White, P. (2005). The language of Evaluation: Appraisal in English. Palgrave Macmillan

Martin, J. R. \& Rose, D. (2007). Working with discourse: Meaning beyond the clause. Continuum.

Martin, J. R. (2014). Evolving systemic functional linguistics: beyond the clause. Functional Linguist, 1, 3. https://doi.org/10.1186/2196-419X-1-3

Martin, J. R. (2017). The discourse semantics of attitudinal relations: Continuing the study of lexis. Russian Journal of Linguistics, 21(1), 22-47. https://doi.org/10.22363/2312918220172112247

Matthiessen, C. M. I. M. (2015a). Register in the round: registerial cartography. Functional Linguist, 2, 9. https://doi.org/10.1186/s40554-015-0015-8

Matthiessen, C. M. I. M. (2015b). Modelling context and register: the long-term project of registerial cartography. Letras, Santa Maria. 25 (50). 15-90.

Matthiessen, C. M. I. M. \& Khasyaf, A. K. (2014). The construal of space in different register: an exploratory study. Language and Science. 45. 1-27. 
O'Sullivan, Sheryl, (2004). Books to live by: Using children's literature for character education. The Reading Teacher. 57 (7), 640-648.

Rose, David (2007). Reading genre: A new wave of analysis. Linguistics and the Human Sciences, 2 (1), 1-30.

Rose, David (2010). Genre in the Sydney school. In the Routledge Handbook of Discourse Analysis, 1-16. James Paul Gee and Mike Handford (eds. Routledge.

Santosa, R. (2003). Semiotika sosial: Pandangan terhadap bahasa. Pustaka Eureka \& Jawa Pos Press.

Santosa, R., Djatmika, D. \& Akhmerti, F. (2007). sastra anak sebagai wahana pengenalan dan pengasuhan ideologi: Sebuah kajian wacana. Laporan Penelitian Fundamental Tahun ke-2.

Santosa, R. (2017). Metode penelitian kualitatifkebahasaan. Surakarta: UNS Press.

Segal, E. (2010). Closure in detective fiction. Poetics Today. 31 (2). 153-215. https://doi.org/10.2307/40984375

Shiro, M. (2003). Genre and evaluation in narrative development. Journal of Child Language, 30 (1), 165-195. https://doi.org/10.1017/S0305000902005500

Spradley, J. P. (2006). Metode etnografi (M. Z. Elizabeth, Trans.). Tiara Wacana.

Tan, E. S. (2011). Emotion and the structure of narrative film: Film as emotion machine. Routledge.

Tupala, M. (2019). Applying quantitative appraisal analysis to the study of institutional discourse: the case of EU migration document. Functional Linguistics, 6(2), 1-17. https://doi.org/10.1186/s40554-018-0067

Tyra, C. (2011). Bringing books to life: Teaching character education through children's literature. Rising Tide, 5, 1-16.

Widyahening, E. T. \& Wardhani, N. E. (2016). Literary work and character education. International Journal of Language and Literature. 4 (1). 176-180. 